\title{
Arsenic trioxide and triptolide synergistically induce apoptosis in the SKM-1 human myelodysplastic syndrome cell line
}

\author{
HAI-YING HUA ${ }^{1,2}$, HUA-QIANG GAO ${ }^{2}$, AI-NING SUN ${ }^{1}$, JIAN-NONG CEN $^{3}$ and LI-LI WU ${ }^{3}$ \\ ${ }^{1}$ Department of Hematology, The First Affiliated Hospital of Soochow University, Suzhou, Jiangsu 215006; \\ ${ }^{2}$ Department of Hematology, The Third Affiliated Hospital of Nantong University, Wuxi, Jiangsu 214041; \\ ${ }^{3}$ Laboratory of Cell and Molecular Biology, Jiangsu Institute of Hematology, Suzhou, Jiangsu 215006, P.R. China
}

Received August 31, 2015; Accepted August 22, 2016

DOI: $10.3892 / \mathrm{mmr} .2016 .5779$

\begin{abstract}
Although certain combination therapies comprising arsenic trioxide $\left(\mathrm{As}_{2} \mathrm{O}_{3}\right)$ with other agents exist for the treatment of several types of human cancer, few $\mathrm{As}_{2} \mathrm{O}_{3}$ combination therapies are clinically effective for myelodysplastic syndromes (MDS). Triptolide (TL) may be an effective therapeutic agent for the treatment of MDS. However, to date, there is no combination therapy for MDS with $\mathrm{As}_{2} \mathrm{O}_{3}$ and TL. Therefore, the aim of the present study was to investigate this combination therapy on the apoptosis of MDS SKM-1 cells. The MDS SKM-1 cells were treated with $\mathrm{As}_{2} \mathrm{O}_{3}$, TL or the two in combination at various concentrations, or were mock-treated. Cell viability, cell apoptosis, levels of reactive oxygen species (ROS) and the expression of the cell apoptosis-associated genes, B cell lymphoma-2 (Bcl-2), Bcl-2-associated X protein (Bax) and caspase-3, were determined using an MTT assay, flow cytometric analysis of annexin V-fluorescein isothiocyanate/propidium iodide double-stained cells, flow cytometic analysis of intracellular 2',7'-dichlorodihydrofluorescein diacetate fluorescence and reverse transcription-quantitative polymerase chain reaction analysis, respectively. Combination index (CI) analysis was performed to determine whether effects were synergistic $(\mathrm{CI}<1)$. The combination treatment was found to synergistically inhibit MDS SKM-1 cell growth, induce cell apoptosis, increase ROS levels, upregulate the expression levels of Bax and caspase-3, and downregulate the mRNA expression of $\mathrm{Bcl}-2$. In conclusion, the combination treatment of $\mathrm{As}_{2} \mathrm{O}_{3}$ and TL synergistically induced apoptosis in the MDS SKM-1 cells.
\end{abstract}

Correspondence to: Dr Ai-Ning Sun, Department of Hematology, The First Affiliated Hospital of Soochow University, 188 Shizi Street, Suzhou, Jiangsu 215006, P.R. China

E-mail: ainingsun@hotmail.com

Key words: myelodysplastic syndromes, arsenic trioxide, triptolide, apoptosis, combination index, reactive oxygen species, B cell lymphoma-2, B cell lymphoma-2-associated X protein, caspase-3

\section{Introduction}

Myelodysplastic syndromes (MDS) are clonal stem cell disorders characterized by peripheral cytopenias with dysplasia in one or more cell lineages, including erythrocytic, granulocytic and megakaryocytic lineages, leading to the progression to acute myelogenous leukemia (AML) with a poor prognosis (1-4). At present, allogeneic hematopoietic stem-cell transplantation is the only treatment option, which can induce long-term remission $(5,6)$. However, its use is only possible in a minority of patients with MDS due to the advanced age of presentation, limited availability of donor sources, high rate of treatment-associated mortality $(\sim 39 \%$ at 1 year), suboptimal disease-free survival rates $(\sim 29 \%$ at 5 years) and chronic graft-versus-host disease $(\sim 15 \%$ at 1 year) (6). Aberrant DNA methylation is frequently associated with MDS; therefore, demethylating agents, including as azacytidine and decitabine, are used to treat patients with MDS. However, treatment of patients with a higher risk of MDS with azacitidine $(7,8)$ only increases the overall survival rate to 24.5 months, compared with 15.0 months with conventional care, supportive care, treatment with low-dose cytarabine or intensive chemotherapy. In addition, treatment with decitabine (9) prolongs the median duration of the progression of AML or associated mortality rates to 12 months, compared with 6.8 months following supportive care alone. In addition, the rates of complete remission (9-17\%) following treatment with demethylating agents (7-9) are similar to those following conventional care with low-dose cytarabine (11-18\%) (10), and substantially lower, compared with those following induction chemotherapy in patients with AML (>50\%) (11). Lenalidomide, a derivative of thalidomide, reduces transfusion requirements, and reverses cytologic and cytogenetic abnormalities in patients who have MDS with the $5 \mathrm{q} 31$ deletion (12). However, lenalidomide increases the risk of developing other malignancies, including AML and B-cell lymphoma (13). Thus, a more effective treatment option for MDS is urgently required.

Arsenic trioxide $\left(\mathrm{As}_{2} \mathrm{O}_{3}\right)$ is a traditional Chinese medicine, which is effective in the clinical management of patients with acute promyelocytic leukemia (APL) $(14,15)$. However, in two-phase II multicenter trials, rates of hematological improvement with $\mathrm{As}_{2} \mathrm{O}_{3}$ were $20-29 \%$, with moderate toxicity 
reported (16,17). $\mathrm{As}_{2} \mathrm{O}_{3}$ induces the apoptosis of nonpromyelocytic leukemia and other types of malignant tumor cells (18-20) through the inhibition of B cell lymphoma-2 (Bcl-2) (21), and the upregulation of Bcl-2-associated X protein (Bax) (22) and caspase-3 (23).

Extracts of the Chinese herb, Tripterygium wilfordii Hook $\mathrm{F}$ are used to treat autoimmune and/or inflammatory diseases, and triptolide (TL) is the active substance of these extracts in vitro and in vivo (24). Several studies have demonstrated that TL may be an effective therapeutic agent for the treatment of MDS (25), several types of human pancreatic (26) and adrenal (27) cancer, and T cell lymphocytic leukemia (28) via inducing cell apoptosis through the activation of caspase-3 and generation of reactive oxygen species (ROS) (25-27).

Although certain combination therapies involving $\mathrm{As}_{2} \mathrm{O}_{3}$ and other agents, are ongoing for several types of human cancer, few $\mathrm{As}_{2} \mathrm{O}_{3}$ combination therapies are clinically effective. These include combination therapy of $\mathrm{As}_{2} \mathrm{O}_{3}$ with ascorbic acid in nonrefractory APL hematologic malignancies and multiple myeloma (18), but not in other AML except nonrefractory APL, acute lymphoid leukemia (18), chronic myeloid leukemia and chronic lymphoid leukemia (18). The use of phase 2 combination therapy with $\mathrm{As}_{2} \mathrm{O}_{3}$ and gemtuzumab ozogamicin for the treatment of MDS and secondary AML has been found to have acceptable response rates and toxicity, however, the median overall survival rate was only 9.7 months (29).

The aim of the present study was to investigate the effect of $\mathrm{As}_{2} \mathrm{O}_{3}$ in combination with TL on the apoptosis of MDS SKM-1 cells by evaluating the gene expression levels of Bcl-2, Bax and caspase-3, and the generation of ROS.

\section{Materials and methods}

Reagents and cell culture. TL (purity $>99.0 \%$; Chinese Academy of Medical Sciences, Nanjing, China) was dissolved in dimethyl sulfoxide (DMSO; Sigma-Aldrich; Thermo Fisher Scientific, Inc., Waltham, MA, USA) to form a $1 \mathrm{mM}$ stock solution. $\mathrm{As}_{2} \mathrm{O}_{3}$ powder (Beijing Double-Crane Pharmaceutical Co., Ltd., Beijing, China) was dissolved in phosphate-buffered saline (PBS). The MDS SKM-1 cell line was obtained from the Cell Bank of the Japanese Collection of Research Bioresources (Osaka, Japan). The SKM-1 cells were cultured in RPMI 1640 medium (Life Technologies; Thermo Fisher Scientific, Inc.) supplemented with $10 \%$ fetal calf serum and $1 \%$ penicillin/streptomycin at $37^{\circ} \mathrm{C}$ in a humidified incubator with $5 \% \mathrm{CO}_{2}$. Cells in the second to fourth passages and logarithmic growth phase, with $>95 \%$ viability on trypan blue staining, were used for the following experiments.

Cell treatment and cell viability assessment using an MTT

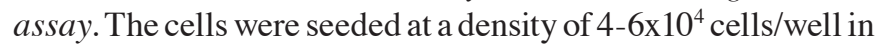
96-well plates, cultured RPMI 1640 medium (Gibco; Thermo Fisher Scientific, Inc.) supplemented with $10 \%$ fetal calf serum and $1 \%$ penicillin/streptomycin mixture at $37^{\circ} \mathrm{C}$ in humidified incubator with $5 \% \mathrm{CO}_{2}$ for $48 \mathrm{~h}$ and treated with various concentrations of $\mathrm{As}_{2} \mathrm{O}_{3}(0.25,0.5,2,8$ or $32 \mu \mathrm{M})$, TL $(10,20,40,80$ or $160 \mathrm{ng} / \mathrm{ml})$ or $\mathrm{As}_{2} \mathrm{O}_{3}+\mathrm{TL}(0.25+10 \mathrm{ng} / \mathrm{ml}$, $0.5+20 \mathrm{ng} / \mathrm{ml}, 2.0+40 \mathrm{ng} / \mathrm{ml}, 8+80 \mathrm{ng} / \mathrm{ml}$ or $32+160 \mathrm{ng} / \mathrm{ml}$ ), or were mock-treated with RPMI-1640 medium containing
$0.002 \%$ DMSO. Following treatment for $48 \mathrm{~h}$, cell viability was assessed using a CellTiter 96 AQueous One Solution Cell Proliferation Assay kit (Promega, Nanjing, China), according to the manufacturer's protocol. The absorbance at $490 \mathrm{~nm}$ was measured using a SpectraMAX M5 spectrophotometer (Molecular Devices, LLC, Sunnyvale, CA, USA).

Flow cytometric analysis of MDS SKM-1 cell apoptosis. Following treatment of the cells for $48 \mathrm{~h}$ with $\mathrm{As}_{2} \mathrm{O}_{3}, \mathrm{TL}, \mathrm{As}_{2} \mathrm{O}_{3}$ and TL, or mock treatment with RPMI-1640 media, the cells were collected by centrifugation at $1,300 \mathrm{x} g$ for $3 \mathrm{~min}$ at room temperature, washed twice with PBS (BD Biosciences, Beijing, China), and resuspended in binding buffer (Novagen; EMD Millipore, Billerica, MA, USA) at $1 \times 10^{6}$ cells $/ \mathrm{ml}$. Subsequently, the cells were stained with $5 \mu \mathrm{l}$ of annexin V-fluorescein isothiocyanate (FITC) and $5 \mu \mathrm{l}$ of propidium iodide (PI), incubated in the dark at room temperature for $15 \mathrm{~min}$, and mixed with binding buffer $(400 \mu \mathrm{l})$. Analysis of apoptosis was then performed on a Calibur flow cytometer (BD Biosciences). Early and late apoptotic cells were calculated based on annexin V-positivity/PI-negativity and annexin V-positivity/ PI-positivity, respectively.

Intracellular ROS. The cells (3×105/well) in 6-well plates were treated with $\mathrm{As}_{2} \mathrm{O}_{3}, \mathrm{TL}, \mathrm{As}_{2} \mathrm{O}_{3}$ and TL or mock treatment, cultured in RPMI 1640 medium, supplemented with 10\% FCS and $1 \%$ penicillin/streptomycin mixture at $37^{\circ} \mathrm{C}$ in humidified incubator with $5 \% \mathrm{CO}_{2}$ for $48 \mathrm{~h}$. Following treatment, the cells were washed once with PBS and treated with $100 \mathrm{nM}$ 2',7'-dichlorodihydrofluorescein diacetate in a cell culture incubator for $30 \mathrm{~min}$ at $37^{\circ} \mathrm{C}$ with $5 \% \mathrm{CO}_{2}$. Following trypsinization, the cells were washed once with PBS and centrifuged at 1,300 $\mathrm{x} g$ for $3 \mathrm{~min}$. The cell pellets were then resuspended in $1 \mathrm{ml}$ PBS and analyzed on a Calibur flow cytometer (BD Biosciences).

Reverse transcription-quantitative polymerase chain reaction $(R T-q P C R)$ analysis. Following the treatment of the cells for $48 \mathrm{~h}$, total RNA was extracted using TRIzol reagent (Invitrogen; Thermo Fisher Scientific, Inc.), according to the manufacturer's protocol. RT-qPCR analysis was performed on an ABI 7900 sequence detection system (Applied Biosystems; Thermo Fisher Scientific, Inc.) using a qRT-PCR kit (Qiagen, Beijing, China), according to the manufacturer's protocol. The Abl gene was used as an internal control. The primer sequences were as follows: Bcl-2, forward (F) 5'-AGG ATCATGCTGTACTTAA-3' and reverse (R) 5'-ATGAGG CACGTTATTATTAG-3'; Bax, F 5'-CGAACTGGACAG TAACAT-3' and R 5'-CTCGGAAAAAGACCTCTC-3'; caspase-3, F 5'-TTGTAGAAGTCTAACTGGAA-3' and R 5'-CCATGTCATCATCAACAC-3'; Abl, F 5'-GATACGAAG GGAGGGTGTACCA-3' and R 5'-CTCGGCCAGGGTGTT GAA-3'. The $25 \mu \mathrm{l}$ PCR reaction system included PCR mix $12.5 \mu \mathrm{l}$, F primer $0.5 \mu \mathrm{l}$, R primer $0.5 \mu \mathrm{l}$, probe $0.3 \mu \mathrm{l}, \mathrm{ddH}_{2} \mathrm{O}$ $7.2 \mu \mathrm{l}$, cDNA $4 \mu \mathrm{l}$. The reaction parameters of $\mathrm{Bcl}-2$, Bax and caspase-3 were as follows: $94^{\circ} \mathrm{C} 5 \mathrm{~min}, 94^{\circ} \mathrm{C} 40 \mathrm{sec}, 56^{\circ} \mathrm{C}$ $55 \mathrm{sec}, 72^{\circ} \mathrm{C} 1 \mathrm{~min}$ for 45 cycles, $72^{\circ} \mathrm{C}$ extension $7 \mathrm{~min} ; 94^{\circ} \mathrm{C}$ $5 \mathrm{~min}, 94^{\circ} \mathrm{C} 40 \mathrm{sec}, 58^{\circ} \mathrm{C} 55 \mathrm{sec}, 72^{\circ} \mathrm{C} 1 \mathrm{~min}$ for 45 cycles, $72^{\circ} \mathrm{C}$ extension $7 \mathrm{~min} ; 94^{\circ} \mathrm{C} 5 \mathrm{~min}, 94^{\circ} \mathrm{C} 40 \mathrm{sec}, 50^{\circ} \mathrm{C} 55 \mathrm{sec}$, $72^{\circ} \mathrm{C} 1 \mathrm{~min}$ for 45 cycles, $72^{\circ} \mathrm{C}$ extension $7 \mathrm{~min}$. The results 

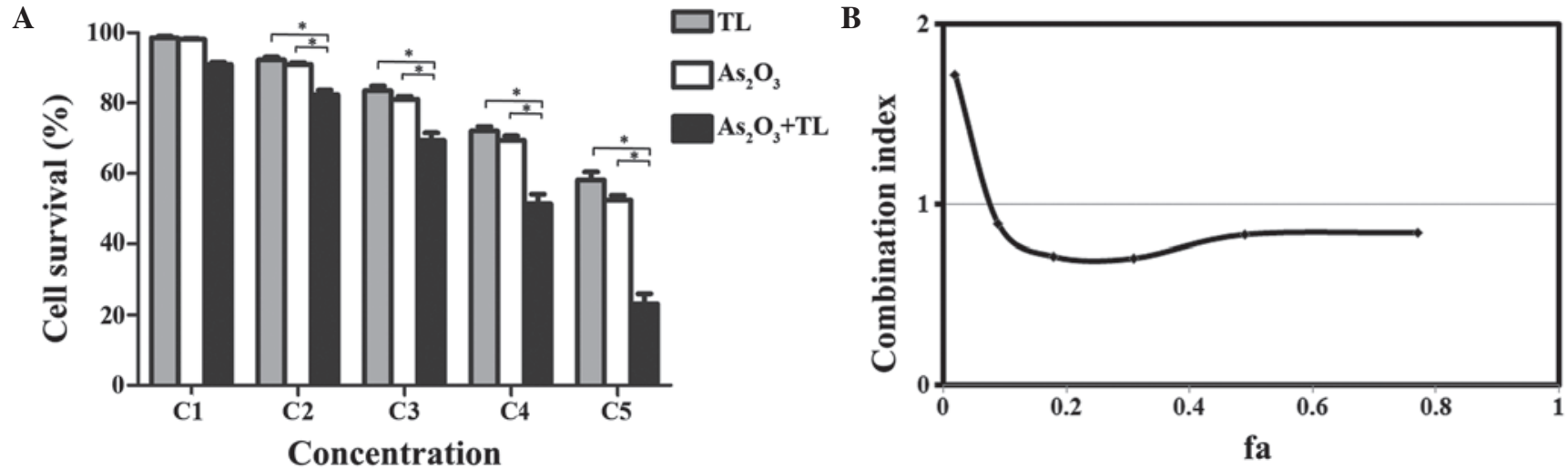

Figure 1. Synergistic effect of $\mathrm{As}_{2} \mathrm{O}_{3}$ and TL on the inhibition of MDS SKM-1 cell growth. (A) MDS SKM-1 cells treated with different concentrations of As $\mathrm{O}_{3}$ $(0.25,0.50,2,8$ or $32 \mu \mathrm{M}$ as C1-C5) and/or TL $(10,20,40,80$ or $160 \mathrm{ng} / \mathrm{ml}$ as C1-C5). Cell growth was measured using an MTT assay. Data are expressed as the mean \pm standard error of the mean ( $\mathrm{P}<0.01 ; \mathrm{n}=5$ ). (B) Combination index of $\mathrm{As}_{2} \mathrm{O}_{3}$ with TL. The 'fa' on the $\mathrm{x}$-axis denotes the fraction affected (i.e., a value of 0.2 is equivalent to a $20 \%$ reduction in cell growth). $\mathrm{As}_{2} \mathrm{O}_{3}$, arsenic trioxide; TL, triptolide; MDS, myelodysplastic syndrome.
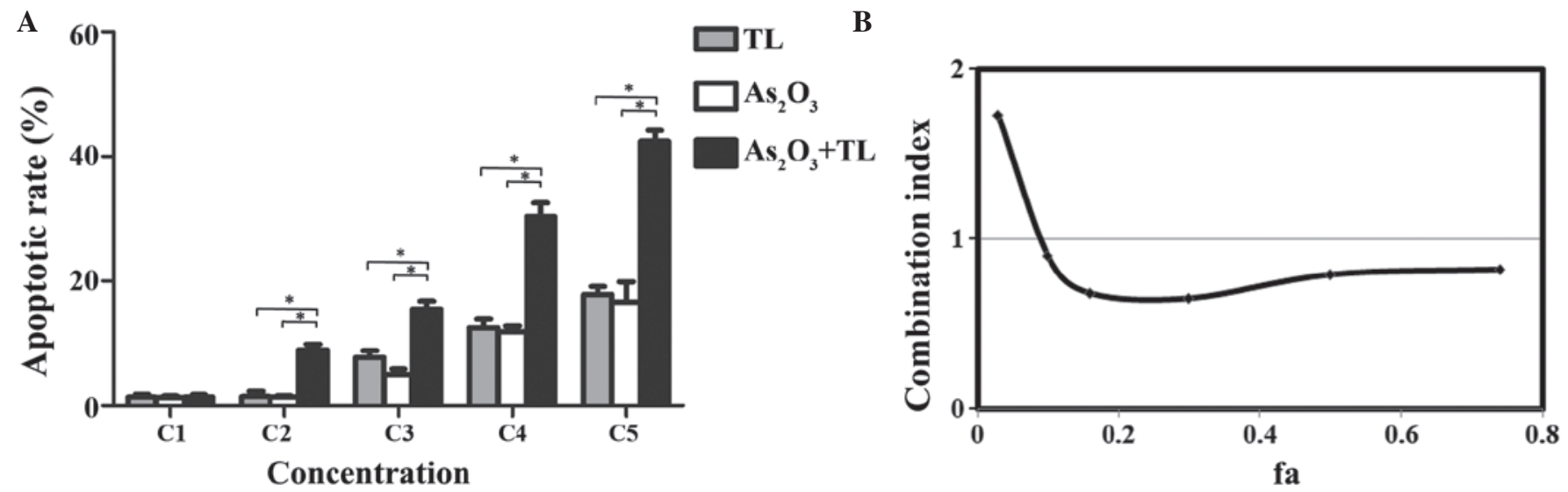

Figure 2. $\mathrm{As}_{2} \mathrm{O}_{3}+\mathrm{TL}$ treatment induces MDS SKM-1 cell apoptosis. The MDS SKM-1 cells were treated with different concentrations of $\mathrm{As}_{2} \mathrm{O}_{3}(0.25,0.50,2,8$ or $32 \mu \mathrm{M}$ as C1-C5) and/or TL (10, 20, 40, 80 or $160 \mathrm{ng} / \mathrm{ml}$ as C1-C5) for $48 \mathrm{~h}$. (A) Flow cytometric analysis of MDS SKM-1 cell apoptosis by double staining with annexin V/PI. Data are expressed as the mean \pm standard error of the mean ("P<0.01; n=5). (B) Combination index of $\mathrm{As}_{2} \mathrm{O}_{3}+\mathrm{TL}$. The 'fa' on the $\mathrm{x}$-axis denotes the fraction affected (i.e., a value of 0.2 is equivalent to a $20 \%$ increase in apoptosis). $\mathrm{As}_{2} \mathrm{O}_{3}$, arsenic trioxide; TL, triptolide; MDS, myelodysplastic syndrome.

were reported as $2^{-\Delta \Delta \mathrm{Cq}}$ relative to the gene expression of Abl (30).

Statistical analysis. Statistical analysis was performed with SPSS version 16.0 (SPSS, Inc., Chicago, IL, USA). Data are expressed as the mean \pm standard error of the mean. Statistical analysis was performed using one-way analysis of variance followed by the least significant difference post-hoc test and Student's $t$-test. Factorial design analysis of variance was used to determine additive or synergistic effects. $\mathrm{P}<0.05$ was considered to indicate a statistically significant difference.

\section{Results}

$\mathrm{As}_{2} \mathrm{O}_{3}$ and TL synergistically inhibit the growth of MDS SKM-1 cells. To examine whether TL enhances the chemosensitivity of MDS SKM-1 cells to $\mathrm{As}_{2} \mathrm{O}_{3}$, the present study examined the growth of MDS SKM-1 cells following treatment with $\mathrm{As}_{2} \mathrm{O}_{3}$ in combination with TL. The combination treatment of $\mathrm{As}_{2} \mathrm{O}_{3}+\mathrm{TL}$ substantially suppressed SKM-1 cell growth, compared with the cells treated with $\mathrm{As}_{2} \mathrm{O}_{3}$ or TL alone (Fig. 1A). To evaluate whether the cell growth inhibition induced by the combination of $\mathrm{TL}+\mathrm{As}_{2} \mathrm{O}_{3}$ was additive or synergistic, the $\mathrm{CI}$ values were determined according to the Chou-Talalay combination index equation $\mathrm{CI}=(\mathrm{C}) 1 /(\mathrm{CX}) 1+(\mathrm{C}) 2 /(\mathrm{CX}) 2+(\mathrm{C}) 1(\mathrm{C}) 2 /(\mathrm{CX}) 1(\mathrm{CX}) 2$ (31), where $\mathrm{CI}<1$ defines synergism. The $\mathrm{CI}$ analysis revealed that the $\mathrm{CI}$ values ranged between 0.70 and 0.87 (Fig. 1B). These results indicated that $\mathrm{As}_{2} \mathrm{O}_{3}$ and TL synergistically inhibited MDS SKM-1 cell growth.

$\mathrm{As}_{2} \mathrm{O}_{3}$ and TL synergistically induce apoptosis in MDS SKM-1 cells. To examine whether $\mathrm{As}_{2} \mathrm{O}_{3}$ and TL synergistically inhibit MDS SKM-1 cell growth through the induction of cell apoptosis by treatment with $\mathrm{As}_{2} \mathrm{O}_{3}$ in combination with TL, cell apoptosis was assessed using flow cytometry with annexin V-FITC/PI double staining. The combination treatment of $\mathrm{As}_{2} \mathrm{O}_{3}+\mathrm{TL}$ substantially induced SKM-1 cell apoptosis, compared with either $\mathrm{As}_{2} \mathrm{O}_{3}$ or TL alone (Fig. 2A). CI analysis revealed that the $\mathrm{CI}$ values ranged between 0.65 and 0.85 (Fig. 2B). The results indicated that $\mathrm{As}_{2} \mathrm{O}_{3}$ and TL synergistically induced MDS SKM-1 cell apoptosis. 

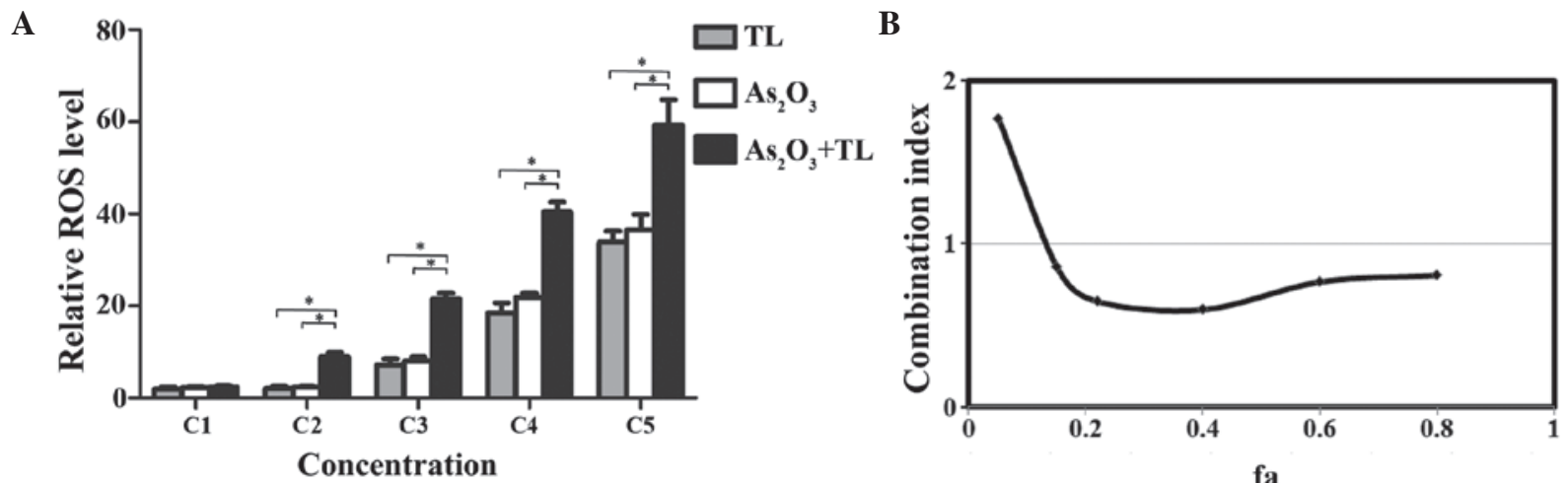

Figure 3. Analysis of ROS in SKM-1 cells using flow cytometry. (A) MDS SKM-1 cells were treated with different concentrations of $\mathrm{As}_{2} \mathrm{O}_{3}(0.25,0.50,2,8$ or $32 \mu \mathrm{M}$ as C1-C5, respectively) and/or TL $(10,20,40,80$ or $160 \mathrm{ng} / \mathrm{ml}$ as C1-C5, respectively) for $48 \mathrm{~h}$. The ROS levels were then determined by counting the cells with 2',7'-dichlorodihydrofluorescein diacetate fluorescence using flow cytometry. Data are expressed as the mean \pm standard error of the mean ( $\mathrm{P}<0.01 ; \mathrm{n}=5$ ). (B) Combination index of $\mathrm{As}_{2} \mathrm{O}_{3}$ with TL. The 'fa' on the $\mathrm{x}$-axis denotes the fraction affected (i.e., a value of 0.2 is equivalent to a $20 \%$ increase in intracellular ROS levels). $\mathrm{As}_{2} \mathrm{O}_{3}$, arsenic trioxide; TL, triptolide; MDS, myelodysplastic syndrome.

A

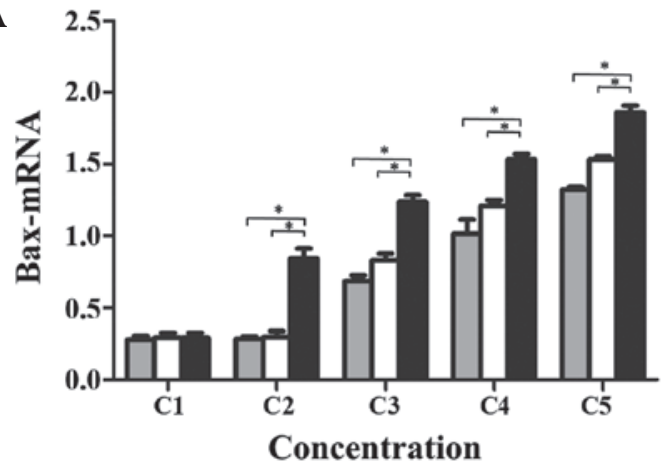

B

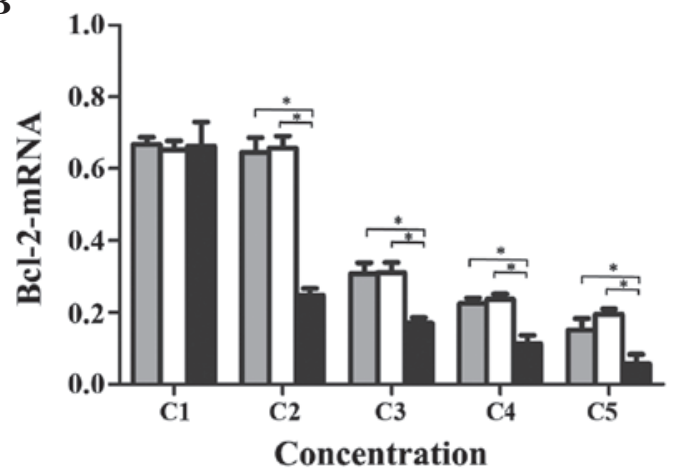

$\square T L$
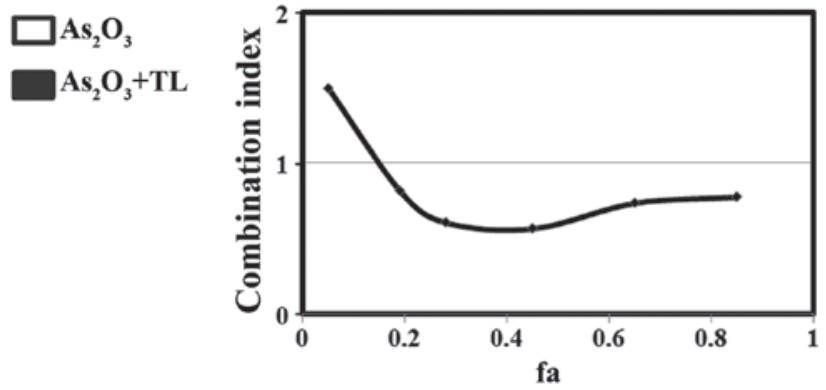

TL

$\square \mathrm{As}_{2} \mathrm{O}_{3}$

$\mathrm{As}_{2} \mathrm{O}_{3}+\mathrm{TL}$

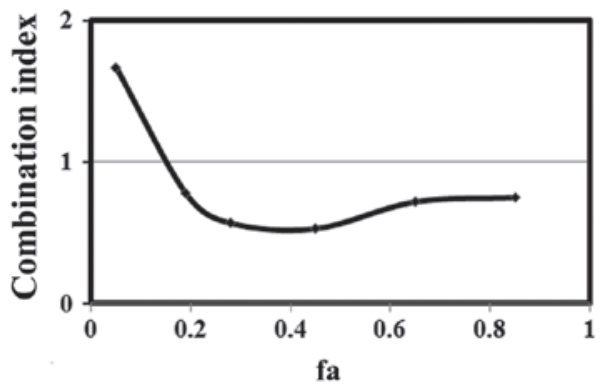

C

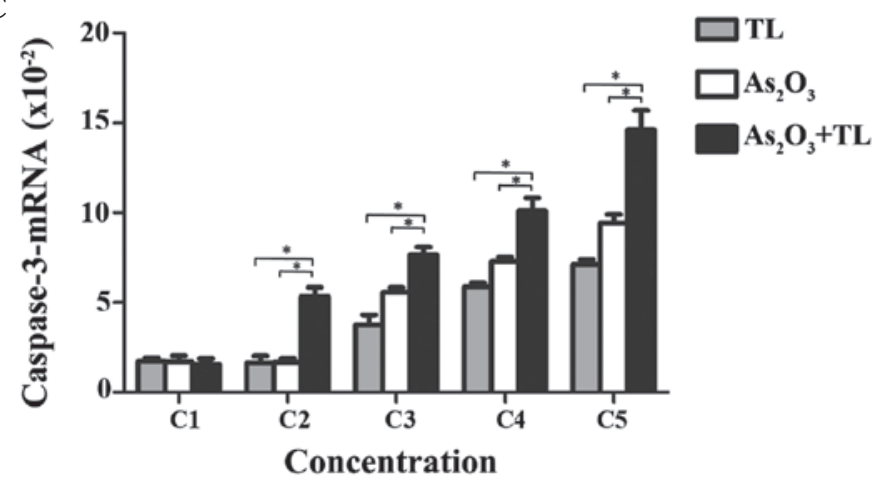

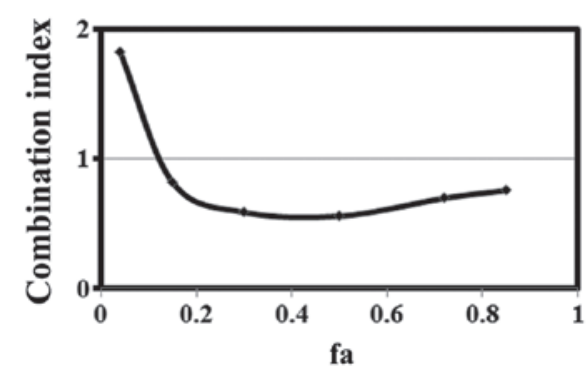

Figure 4. mRNA levels of apoptosis-associated genes in MDS SKM-1 cells. MDS SKM-1 cells were treated with different concentrations of $\mathrm{As}_{2} \mathrm{O}_{3}(0.25$, $0.50,2,8$ or $32 \mu \mathrm{M}$ as C1-C5) and/or TL (10, 20, 40, 80 or $160 \mathrm{ng} / \mathrm{ml}$ as C1-C5) for $48 \mathrm{~h}$. The mRNA expression levels were determined by reverse transcription-quantitative polymerase chain reaction analysis, and quantified using the $2^{-\Delta \Delta C q}$ method relative to Abl. Combination treatment led to a significant (A) increase in the mRNA expression of Bax ("P<0.01), decrease in the mRNA expression of (B) Bcl-2 ("P $<0.01)$ and $(\mathrm{C})$ increase in the mRNA expression of caspase-3 $\left({ }^{*} \mathrm{P}<0.01\right)$. Data are expressed as the mean \pm standard error of the mean $\left(\mathrm{n}=5 ;{ }^{*} \mathrm{P}<0.01\right)$. The graphs on the right show the combination index of $\mathrm{As}_{2} \mathrm{O}_{3}+\mathrm{TL}$. The 'fa' on the x-axis denotes the fraction affected (i.e., 0.2 is equivalent to a $20 \%$ change in mRNA expression). $\mathrm{As}_{2} \mathrm{O}_{3}$, arsenic trioxide; TL, triptolide; MDS, myelodysplastic syndrome; Bcl-2, B cell lymphoma-2; Bax, Bcl-2-associated X protein. 


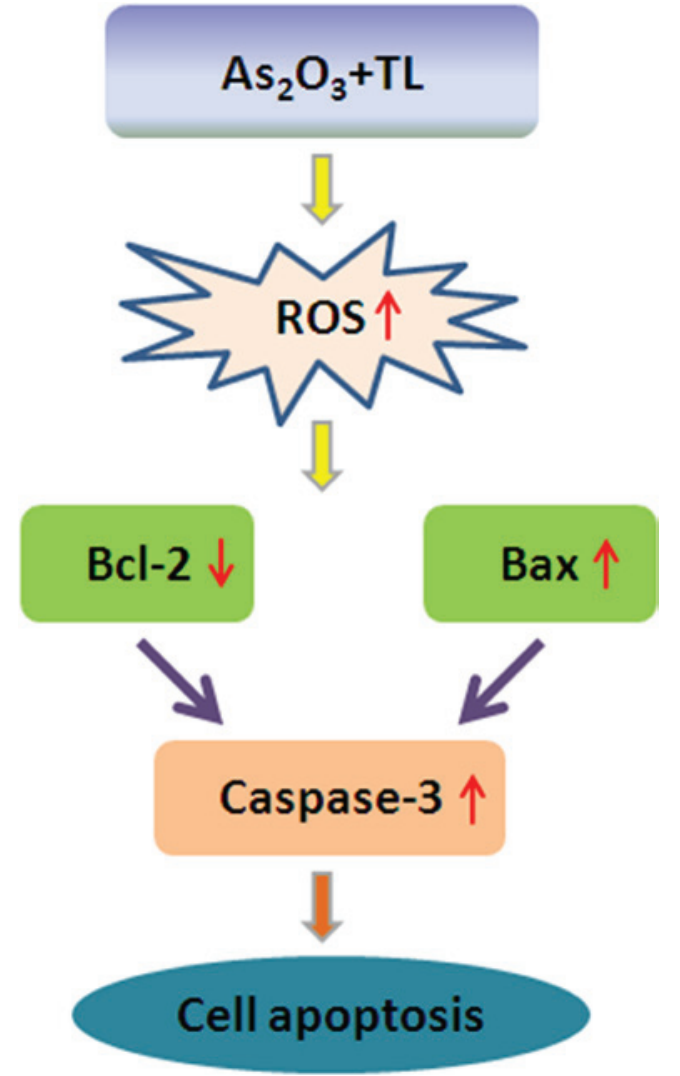

Figure 5. Schematic diagram of the potential mechanism of $\mathrm{As}_{2} \mathrm{O}_{3}$ and TL synergistically inducing MDS SKM-1 cell apoptosis. As2O3 + TL synergistically increased MDS SKM-1 intracellular ROS levels, which upregulated Bax expression, downregulated $\mathrm{Bcl}-2$ expression, upregulated caspase-3 expression and induced cell apoptosis. $\mathrm{As}_{2} \mathrm{O}_{3}$, arsenic trioxide; TL, triptolide MDS, myelodysplastic syndrome; ROS, reactive oxygen species; Bcl-2, B cell lymphoma-2; Bax, Bcl-2-associated X protein.

$\mathrm{As}_{2} \mathrm{O}_{3}$ and TL synergistically induce apoptosis via the generation of ROS in MDS SKM-1 cells. Treatment with $\mathrm{As}_{2} \mathrm{O}_{3}$ in combination with TL substantially increased the intracellular ROS levels, compared with either $\mathrm{As}_{2} \mathrm{O}_{3}$ or TL alone (Fig. 3A; $\mathrm{P}<0.01)$. $\mathrm{CI}$ analysis revealed that the $\mathrm{CI}$ values ranged between 0.60 and 0.86 (Fig. 3B). The results indicated that $\mathrm{As}_{2} \mathrm{O}_{3}$ and TL synergistically induced MDS SKM-1 cell apoptosis via the generation of ROS.

$\mathrm{As}_{2} \mathrm{O}_{3}$ and $\mathrm{TL}$ synergistically regulate the expression of apoptosis-associated genes in MDS SKM-1 cells. To determine whether $\mathrm{As}_{2} \mathrm{O}_{3}$ in combination with TL synergistically regulates the expression of apoptosis-associated genes, the mRNA expression levels of Bax, $\mathrm{Bcl}-2$ and caspase- 3 were measured in the cells treated with $\mathrm{As}_{2} \mathrm{O}_{3}$, TL or $\mathrm{As}_{2} \mathrm{O}_{3}+\mathrm{TL}$ for $48 \mathrm{~h}$. As shown in Fig. 4, treatment with $\mathrm{As}_{2} \mathrm{O}_{3}+\mathrm{TL}$ led to significant increases in the expression levels of Bax and caspase- 3 , and a significant decrease in the mRNA expression of $\mathrm{Bcl}-2$, compared with either $\mathrm{As}_{2} \mathrm{O}_{3}$ or $\mathrm{TL}$ alone $(\mathrm{P}<0.01$; Fig. 4A-C). These results demonstrated that the combination of $\mathrm{As}_{2} \mathrm{O}_{3}$ and TL significantly induced apoptotic activity via inhibiting $\mathrm{Bcl}-2$ and promoting the expression of Bax and caspase-3. CI analysis revealed that the CI values were 0.57-0.82 for Bax (Fig. 4A), 0.53-0.78 for Bcl-2 (Fig. 4B) and 0.56-0.82 for caspase-3 (Fig. 4C). These results indicated that $\mathrm{As}_{2} \mathrm{O}_{3}$ and TL synergistically induced MDS SKM-1 cell apoptosis via increasing the mRNA expression levels of Bax and caspase- 3 and decreasing the mRNA expression of $\mathrm{Bcl}-2$.

\section{Discussion}

To investigate whether TL enhances the chemosensitivity of MDS SKM-1 cells to $\mathrm{As}_{2} \mathrm{O}_{3}$, the present study treated MDS SKM-1 cells with $\mathrm{As}_{2} \mathrm{O}_{3}$, TL or the two in combination. It was found that $\mathrm{As}_{2} \mathrm{O}_{3} / \mathrm{TL}$ synergistically inhibited SKM-1 cell growth through upregulation of ROS levels and cell apoptosis, as evidenced by synergistically increased expression levels of Bax and caspase-3, and decreased mRNA expression of Bcl-2.

The present study found that $\mathrm{As}_{2} \mathrm{O}_{3}+\mathrm{TL}$ synergistically induced MDS SKM-1 cell apoptosis, determined from analysis of annexin V-FITC/PI double staining using flow cytometry. Of note, $\mathrm{As}_{2} \mathrm{O}_{3}$, in combination with a mitogen-activated protein kinase kinase or proteinase (32) inhibitor, has been shown experimentally to have a synergistic effect on the induction of AML cell apoptosis. The present study also found that the combination treatment with $\mathrm{As}_{2} \mathrm{O}_{3}$ and TL resulted in a significant increase in the mRNA expression levels of Bax and caspase-3, and a significant decrease in the mRNA expression of $\mathrm{Bcl}-2$, compared with the cells treated with either $\mathrm{As}_{2} \mathrm{O}_{3}$ or TL alone. To evaluate whether the combination of TL and $\mathrm{As}_{2} \mathrm{O}_{3}$ increased the mRNA expression levels of Bax and caspase- 3 and decreased the mRNA expression of Bcl-2 in an additive or synergistic manner, the $\mathrm{CI}$ values were determined. The results indicated that $\mathrm{As}_{2} \mathrm{O}_{3}+\mathrm{TL}$ synergistically induced MDS SKM-1 cell apoptosis via increasing the mRNA expression levels of Bax and caspase-3 and decreasing the expression of Bcl-2 $(\mathrm{CI}<1)$. These results suggested that the synergistic cell apoptosis induced by the combination treatment resulted from inhibiting the mRNA expression of Bcl-2 and promoting the mRNA expression levels of Bax and caspase-3. It has been reported previously that $\mathrm{As}_{2} \mathrm{O}_{3}$ induces cell apoptosis via the upregulation of Bax (21) and the Bax/Bcl-2 ratio (22), and the downregulation of Bcl-2 (18). Caspase-3 is a member of the cysteine-aspartic acid protease family (33), and sequential activation of caspase proteins is central to the apoptosis of a variety of cancer cells $(21-23,26)$. TL induces human breast and prostate cancer cell apoptosis (33), and TL in combination with tumor-necrosis factor-related apoptosis-inducing ligand enhances the apoptosis of cholangiocarcinoma cells by increasing the activity caspase-3 (34). In addition, the combination treatment of low-dose 1,25-dihydroxyvitamin $\mathrm{D}(3)$ combined with $\mathrm{As}_{2} \mathrm{O}_{3}$ synergistically inhibits AML cell proliferation via cell apoptosis mediated by the increased expression levels of Bax and caspase-3, and decreased expression of Bcl-2 (34).

The present study also found that the combination treatment of $\mathrm{As}_{2} \mathrm{O}_{3}$ with TL synergistically increased the generation of ROS in the cells. Therefore, it was hypothesized that the induction of cell apoptosis by the combination treatment in the present study was mediated by the generation of ROS. It is well known that the presence of increased intracellular ROS in the mitochondria is involved in the induction of apoptosis in cancer cells, and that an increased intracellular ROS concentration has been shown to cause an increase in the $\mathrm{Bax} / \mathrm{Bcl}-2$ ratio and activation of caspase- $3(35,36)$. In the present study, it was 
found that, compared with the cells treated with either $\mathrm{As}_{2} \mathrm{O}_{3}$ or TL alone, the generation of intracellular ROS was significantly increased following exposure to $\mathrm{As}_{2} \mathrm{O}_{3}$ and TL in combination. TL has been found to induce human adrenal cancer NCI-H295 cell apoptosis through the ROS pathway (27), and treatments involving the combination of $\mathrm{As}_{2} \mathrm{O}_{3}$ and sulindac (34) or phytosphingosine (37) have been shown to enhance apoptotic cell death via increasing intracellular ROS.

In conclusion, the present study demonstrated that treatment with $\mathrm{As}_{2} \mathrm{O}_{3}$ in combination with TL synergistically induced MDS SKM-1 cell apoptosis via the induction of intracellular ROS, which upregulated the expression of Bax, downregulated the expression of Bcl-2 and upregulated the expression of caspase-3 (Fig. 5). These findings may provide a strategy to develop a novel combination therapy against MDS.

\section{Acknowledgements}

The present study was supported by a grant (grant no. LZ09103) from the Jiangsu Provincial Bureau of traditional Chinese Medicine (Jaingsu, China).

\section{References}

1. Cogle CR, Craig BM, Rollison DE and List AF: Incidence of the myelodysplastic syndromes using a novel claims-based algorithm: High number of uncaptured cases by cancer registries. Blood 117: 7121-7125, 2011.

2. Jädersten M and Hellström-Lindberg E: Myelodysplastic syndromes: Biology and treatment. J Intern Med 265: 307-328, 2009.

3. Tefferi A and Vardiman JW: Myelodysplastic syndromes. N Engl J Med 361: 1872-1885, 2009.

4. Gore SD and Hermes-DeSantis ER: Enhancing survival outcomes in the management of patients with higher-risk myelodysplastic syndromes. Cancer Control 16 (Suppl): S2-S10, 2009.

5. Chang C, Storer BE, Scott BL, Bryant EM, Shulman HM, Flowers ME, Sandmaier BM, Witherspoon RP, Nash RA, Sanders JE, et al: Hematopoietic cell transplantation in patients with myelodysplastic syndrome or acute myeloid leukemia arising from myelodysplastic syndrome: Similar outcomes in patients with de novo disease and disease following prior therapy or antecedent hematologic disorders. Blood 110: 1379-1387, 2007.

6. Warlick ED, Cioc A, Defor T, Dolan M and Weisdorf D: Allogeneic stem cell transplantation for adults with myelodysplastic syndromes: Importance of pretransplant disease burden. Biol Blood Marrow Transplant 15: 30-38, 2009.

7. Fenaux P, Mufti GJ, Hellstrom-Lindberg E, Santini V, Finelli C, Giagounidis A, Schoch R, Gattermann N, Sanz G, List A, et al: Efficacy of azacitidine compared with that of conventional care regimens in the treatment of higher-risk myelodysplastic syndromes: A randomised, open-label, phase III study. Lancet Oncol 10: 223-232, 2009.

8. Gore SD, Fenaux P, Santini V, Bennett JM, Silverman LR, Seymour JF, Hellström-Lindberg E, Swern AS, Beach CL and List AF: A multivariate analysis of the relationship between response and survival among patients with higher-risk myelodysplastic syndromes treated within azacitidine or conventional care regimens in the randomized AZA-001 trial. Haematologica 98: 1067-1072, 2013.

9. Kantarjian H, Issa JP, Rosenfeld CS, Bennett JM, Albitar M, DiPersio J, Klimek V, Slack J, de Castro C, Ravandi F, et al: Decitabine improves patient outcomes in myelodysplastic syndromes: Results of a phase III randomized study. Cancer 106: 1794-1803, 2006.

10. Zwierzina H, Suciu S, Loeffler-Ragg J, Neuwirtova R, Fenaux P, Beksac M, Harousseau J, Nuessler V, Cermak J, Solbu G, et al: Low-dose cytosine arabinoside (LD-AraC) vs. LD-AraC plus granulocyte/macrophage colony stimulating factor vs. LD-AraC plus Interleukin-3 for myelodysplastic syndrome patients with a high risk of developing acute leukemia: Final results of a randomized phase III study (06903) of the EORTC Leukemia Cooperative Group. Leukemia 19: 1929-1933, 2005.
11. Beran M, Shen Y, Kantarijian H, O'Brien S, Koller CA, Giles FJ, Cortes J, Thomas DA, Faderl S, Despa S and Estey EH: High-dose chemotherapy in high-risk myelodysplastic syndrome: Covariate-adjusted comparison of five regimens. Cancer 92: 1999-2015, 2001.

12. List A, Dewald G, Bennett J, Giagounidis A, Raza A, Feldman E, Powell B, Greenberg P, Thomas D, Stone R, et al: Lenalidomide in the myelodysplastic syndrome with chromosome $5 \mathrm{q}$ deletion. N Engl J Med 355: 1456-1465, 2006.

13. Badros AZ: Lenalidomide in myeloma-a high-maintenance friend. N Engl J Med 366: 1836-1838, 2012.

14. Lallemand-Breitenbach V, Zhu J, Chen Z and de Thé H: Curing APL through PML/RARA degradation by As2O3. Trends Mol Med 18: 36-42, 2012.

15. Shen ZX, Chen GQ, Ni JH, Li XS, Xiong SM, Qiu QY, Zhu J, Tang W, Sun GL, Yang KQ, et al: Use of arsenic trioxide (As2O3) in the treatment of acute promyelocytic leukemia (APL): II. Clinical efficacy and pharmacokinetics in relapsed patients. Blood 89: 3354-3360, 1997.

16. Schiller GJ, Slack J, Hainsworth JD, Mason J, Saleh M, Rizzieri D, Douer D and List AF: Phase II multicenter study of arsenic trioxide in patients with myelodysplastic syndromes. J Clin Oncol 24: 2456-2464, 2006.

17. Vey N, Bosly A, Guerci A, Feremans W, Dombret H, Dreyfus F, Bowen D, Burnett A, Dennis M, Ribrag V, et al: Arsenic trioxide in patients with myelodysplastic syndromes: A phase II multicenter study. J Clin Oncol 24: 2465-2471, 2006.

18. Takahashi S: Combination therapy with arsenic trioxide for hematological malignancies. Anticancer Agents Med Chem 10: 504-510, 2010.

19. Xia J, Li Y, Yang Q, Mei C, Chen Z, Bao B, Ahmad A, Miele L, Sarkar FH and Wang Z: Arsenic trioxide inhibits cell growth and induces apoptosis through inactivation of notch signaling pathway in breast cancer. Int J Mol Sci 13: 9627-9641, 2012.

20. Hoffman E and Mielicki WP: Arsenic trioxide: Impact on the growth and differentiation of cancer cells and possible use in cancer therapy. Postepy Hig Med Dosw (Online) 67: 817-827, 2013 (In Polish).

21. Zhao H, Guo W, Peng C, Ji T and Lu X: Arsenic trioxide inhibits the growth of adriamycin resistant osteosarcoma cells through inducing apoptosis. Mol Biol Rep 37: 2509-2515, 2010.

22. Li C, Qu X, Xu W, Qu N, Mei L, Liu Y, Wang X, Yu X, Liu Z, Nie D, et al: Arsenic trioxide induces cardiac fibroblast apoptosis in vitro and in vivo by up-regulating TGF- $\beta 1$ expression. Toxicol Lett 219: 223-230, 2013.

23. Yedjou C, Tchounwou P, Jenkins $\mathrm{J}$ and McMurray R: Basic mechanisms of arsenic trioxide (ATO)-induced apoptosis in human leukemia (HL-60) cells. J Hematol Oncol 3: 28, 2010.

24. Han R, Rostami-Yazdi M, Gerdes S and Mrowietz U: Triptolide in the treatment of psoriasis and other immune-mediated inflammatory diseases. Br J Clin Pharmacol 74: 424-436, 2012.

25. Deng J and Jin J: Study of triptolide-induced apoptosis in MUTZ-1 cells and its allied mechanism. Zhongguo Shi Yan Xue Ye Xue Za Zhi 13: 434-439, 2005 (In Chinese).

26. Mujumdar N, Mackenzie TN, Dudeja V, Chugh R, Antonoff MB, Borja-Cacho D, Sangwan V, Dawra R, Vickers SM and Saluja AK: Triptolide induces cell death in pancreatic cancer cells by apoptotic and autophagic pathways. Gastroenterology 139: 598-608, 2010

27. Wu PP, Liu KC, Huang WW, Ma CY, Lin H, Yang JS and Chung JG: Triptolide induces apoptosis in human adrenal cancer NCI-H295 cells through a mitochondrial-dependent pathway. Oncol Rep 25: 551-557, 2011.

28. Meng HT, Zhu L, Ni WM, You LS, Jin J and Qian WB: Triptolide inhibits the proliferation of cells from lymphocytic leukemic cell lines in association with downregulation of NF- $\mathrm{BB}$ activity and miR-16-1*. Acta Pharmacol Sin 32: 503-511, 2011.

29. Sekeres MA, Maciejewski JP, Erba HP, Afable M, Englehaupt R, Sobecks R, Advani A, Seel S, Chan J and Kalaycio ME: A Phase 2 study of combination therapy with arsenic trioxide and gemtuzumab ozogamicin in patients with myelodysplastic syndromes or secondary acute myeloid leukemia. Cancer 117: 1253-1261, 2011.

30. Livak KJ and Schmittgen TD: Analysis of relative gene expression data using real-time quantitative PCR and the 2(-Delta Delta C(T)) method. Methods 25: 402-408, 2001.

31. Chou TC and Talalay P: Quantitative analysis of dose-effect relationships: The combined effects of multiple drugs or enzyme inhibitors. Adv Enzym Regul 22: 27-55, 1984. 
32. Takahashi S, Harigae H, Yokoyama H, Ishikawa I, Abe S, Imaizumi M, Sasaki T and Kaku M: Synergistic effect of arsenic trioxide and flt 3 inhibition on cells with flt 3 internal tandem duplication. Int J Hematol 84: 256-261, 2006.

33. Li M, Ding Y, Mu Y, Ao J and Chen X: Molecular cloning and characterization of caspase-3 in large yellow croaker (Pseudosciaena crocea). Fish Shellfish Immunol 30: 910-916, 2011.

34. Clawson KA, Borja-Cacho D, Antonoff MB, Saluja AK and Vickers SM: Triptolide and TRAIL combination enhances apoptosis in cholangiocarcinoma. J Surg Res 163: 244-249, 2010.
35. Spampanato C, De Maria S, Sarnataro M, Giordano E, Zanfardino M, Baiano S, Cartenì M, Morelli F: Simvastatin inhibits cancer cell growth by inducing apoptosis correlated to activation of Bax and down-regulation of BCL-2 gene expression. International J Onco 40: 935-941, 2012

36. Abdelrahman IY, Helwa R, Elkashef H, Hassan NH: Induction of P3NS1 myeloma cell death and cell cycle arrest by simvastatin and/or $\gamma$-radiation. Asian Pac J Cancer Prev 16: 7103-7110,2015.

37. Park MT, Kang YH, Park IC, Kim CH, Lee YS, Chung HY and Lee SJ: Combination treatment with arsenic trioxide and phytosphingosine enhances apoptotic cell death in arsenic trioxide-resistant cancer cells. Mol Cancer Ther 6: 82-92, 2007. 